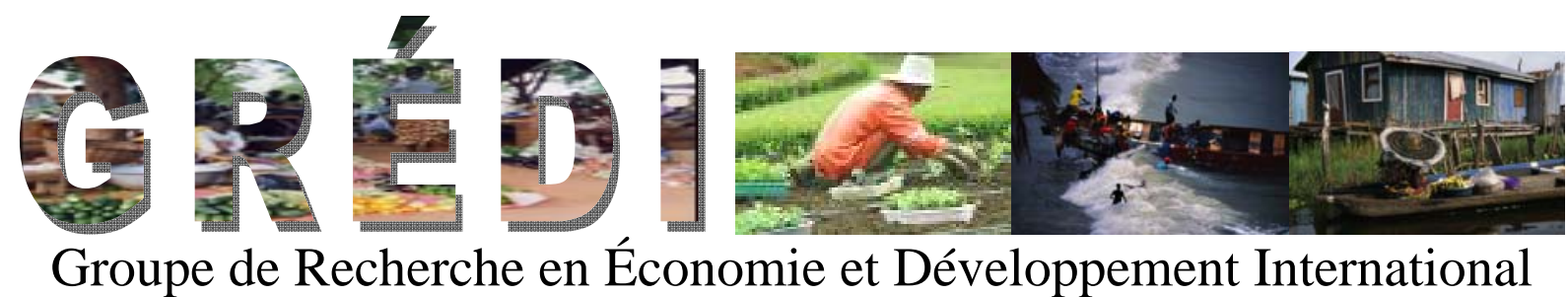

Cahier de recherche / Working Paper

08-20

\title{
The Food Crisis and its Impacts on Poverty in Senegal and Mali: Crossed Destinies
}

Dorothée Boccanfuso

Luc Savard

SI UNIVERSTTÉDE 


\title{
The Food Crisis and its Impacts on Poverty in Senegal and Mali: Crossed Destinies
}

\author{
Dorothée Boccanfuso ${ }^{1}$ \& Luc Savard ${ }^{2}$
}

November 2008

Revised

May 2009

\begin{abstract}
:
In this paper we use a CGE macro-micro modelling approach to analyse the distributional impact of the food crisis and to examine a couple of policy responses in two neighbouring West African countries. Both countries are strongly dependent on agriculture; both have similar climates and share many other features. However, the approach we use captures structural differences at both the macro level and the micro level for household income and expenditure structures. Our results reveal surprising and significant differences for poverty impact at the national and sub-group levels, as well as for inequality and pro-poor analysis. These differences are present for the world price increase of agricultural goods as well as policy responses to the food crisis. Our results highlight the importance of country-specific analysis and the risk of extrapolating conclusions from one country to another.
\end{abstract}

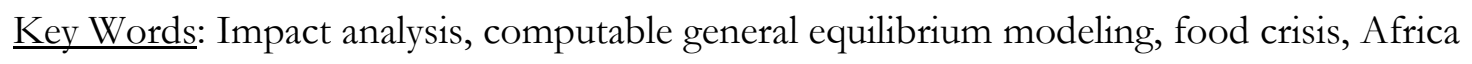
JEL codes: D58, I32, O57, Q18, R13

\footnotetext{
${ }^{1}$ Département d'économique et GRÉDI, Université de Sherbrooke, 2500, boulevard de l’Université, Sherbrooke, Québec, Canada, J1K 2R1; Courriel: dorothee.boccanfuso@USherbrooke.ca.

${ }^{2}$ Département d'économique et GRÉDI, Université de Sherbrooke, 2500, boulevard de l’Université, Sherbrooke, Québec, Canada, J1K 2R1; Courriel: luc.savard@USherbrooke.ca.
} 


\section{Introduction}

Although public awareness of the food crisis and malnutrition was notably raised in the beginning of 2008, international institutions and especially the Food and Agriculture Organization (FAO) have in fact been working for over 50 years at reducing and eradicating food insecurity in the world. In 1960, the FAO had already launched the Freedom From Hunger Campaign, a world-wide campaign to help find possible solutions to the problem. In 1996, more than 180 governments adopted the Rome Declaration on World Food Security as well as the World Food Summit Plan of Action, in which they committed to bringing about important changes in policies and programmes needed to achieve Food for All. One of their main objectives is to reduce by half the number of undernourished people by the year 2015 .

Ten years after the World Food Summit, the number of undernourished people in the world remains persistently high, with an estimated 848 million people in 2003-05. During this period, weather conditions and natural events caused food emergencies. Although it may seem to be more of a demand side problem than a production one, crop and livestock production also fell sharply in 2005 due to the decrease in production of developed countries and to animal disease outbreaks, such as Avian Influenza. Furthermore, only some food prices began to increase; those for the main cereals remained more stable. However, since the end of 2006, the situation has continued to deteriorate with the rise in cereal prices and other food commodities. Agricultural prices rose sharply in 2007 and continued to rise even more sharply in the first three months of 2008 (Figure 1).

Figure 1 : Annual food price indices of selected food and feed commodities (2002-2004=100)

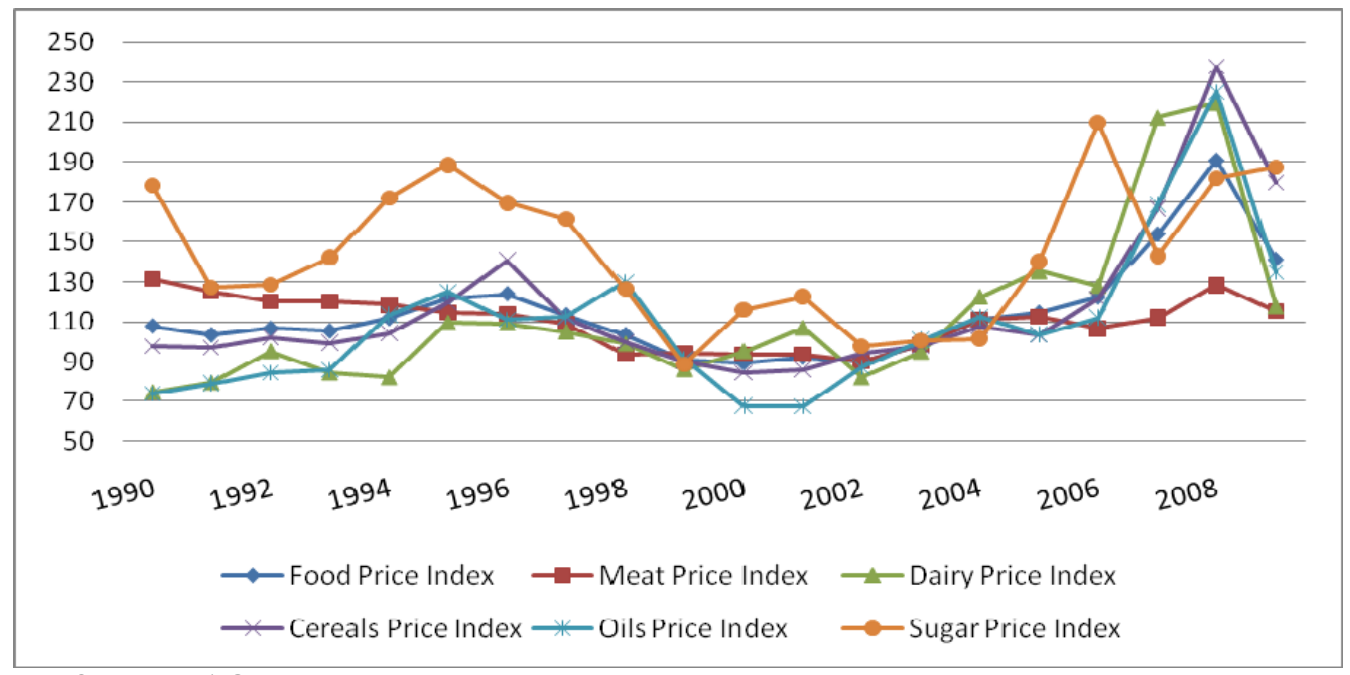

Source: FAO, May 2009. 
Several factors are considered as underlying the current state of the food market. Poor harvests in major producing countries linked to extreme weather events such as cereal production in Australia (drought) and the decline of world food stocks are both linked to the supply side. Increasing fuel costs raising the agricultural production and transportations for inputs and food costs seem to be another important factor in the rise of food prices. The observed lack of investments in the agricultural sector could also be considered a major cause of the crisis. Productive capacities have declined over several decades, reducing the number of small and productive rural lands and de facto the purchasing power of rural households. Moreover, among identified factors, the subsidized production of biofuels that substitute for food production appears to be one of the major drivers even there is no consensus regarding the effective range of the contribution of biofuels as a factor in high food prices. Finally, the changing structure of demand, speculative activities, and export constraints are also considered as factors that could explain the increase of food commodity prices. The insufficiency in supply combined with an ever-increasing demand marked the beginning of the 2008 world food crisis.

Which countries are particularly affected by this food crisis? The FAO estimated that lowincome and net importing countries (LIFDC) will pay 40\% more in 2008 than in 2007 for their food imports. For Africa, the total cereal import bill in 2007/08 is predicted to increase by 23\% compared to 2006/07. Even if the FAO estimates that another 75 million people are being pushed back into hunger around the world, the impact of the rise in prices on the standard of living is more difficult to isolate because of particular characteristics of populations (rural versus urban, farming versus non farming, etc.).

This study positions itself in this context since we want to analyse the impacts of these commodity price increases on the populations of two developing countries, namely Senegal and Mali. Moreover, since some governments of developing countries rapidly reacted to this increase in food prices, we also wanted to analyse the impacts of two emergency policies. Increased land use for agriculture and cuts in import duties are two examples of policies that were put into place in several countries. We investigate the impacts of these reforms at the national level but also on rural and urban households in Mali and Senegal in a CGE macromicro context. The direct effects described above do not take into account major impact of food price increase on the rest of the economy. As we will describe below, our approach allows 
us to refine the distributional analysis by taking into account both the direct and indirect effect of a food crisis.

In the next section, the Malian and Senegalese situations are briefly presented to provide some preliminary indications of results from the analysis presented in the latter part of the paper. Next, the main features of the CGE models for the both countries are explained (section 3). In the fourth part we describe the simulations performed, and in the following section (section 5), macroeconomic and sectoral results are analysed, while section 6 is dedicated to the analysis of the distribution impacts of external shocks and policies on Malian and Senegalese households. We conclude in the final section.

\section{The food crisis in Mali and Senegal}

\subsection{The agticultural situation in Senegal and Mali}

Between 1984 and 1993, the contribution of the national production of cereals to the needs of the Senegalese population was near 60\%; imports and food aid filled the remaining gap. From 1994 to 2000, this relative share fell to 50\% (Cabral, 2005). In 2002-03, national production covered $41.3 \%$ of national demand and $10.3 \%$ came from available stocks (FAO, 2002b, 2004) ${ }^{3}$. As shown in Figure 2, Senegal is strongly dependent on imports to satisfy its demand for rice and wheat since the 60's.

Figure 2: Rice and wheat consumption, exports, imports and production in Senegal
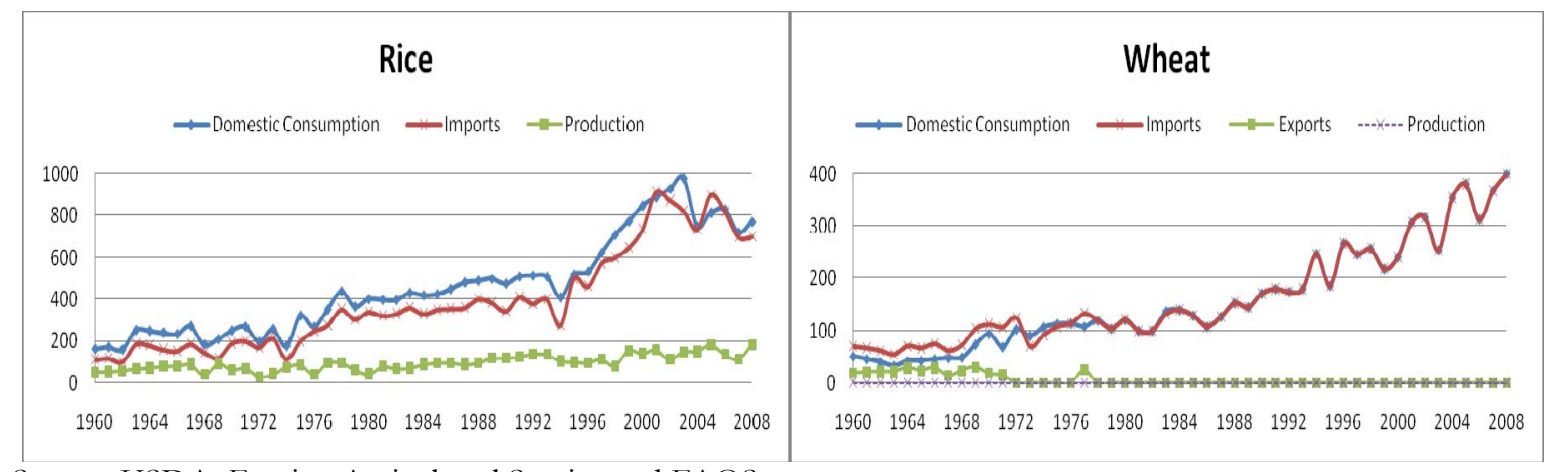

Source: USDA, Foreign Agricultural Service and FAOStat

The situation is completely different for Mali, where cereal needs are mostly satisfied by national production from year to year. As figures for 2004-05 illustrate in Table 7, no imports were needed for rice, and wheat was the main imported cereal, despite representing only about

\footnotetext{
${ }^{3}$ See Table 7 in appendix.
} 
$2 \%$ of total cereal demand. As opposed to the Senegalese situation for rice, Mali has been relatively successful in satisfying the domestic demand with the national production (Figure 3)

Figure 3: Rice and wheat consumption, exports, imports and production in Mali
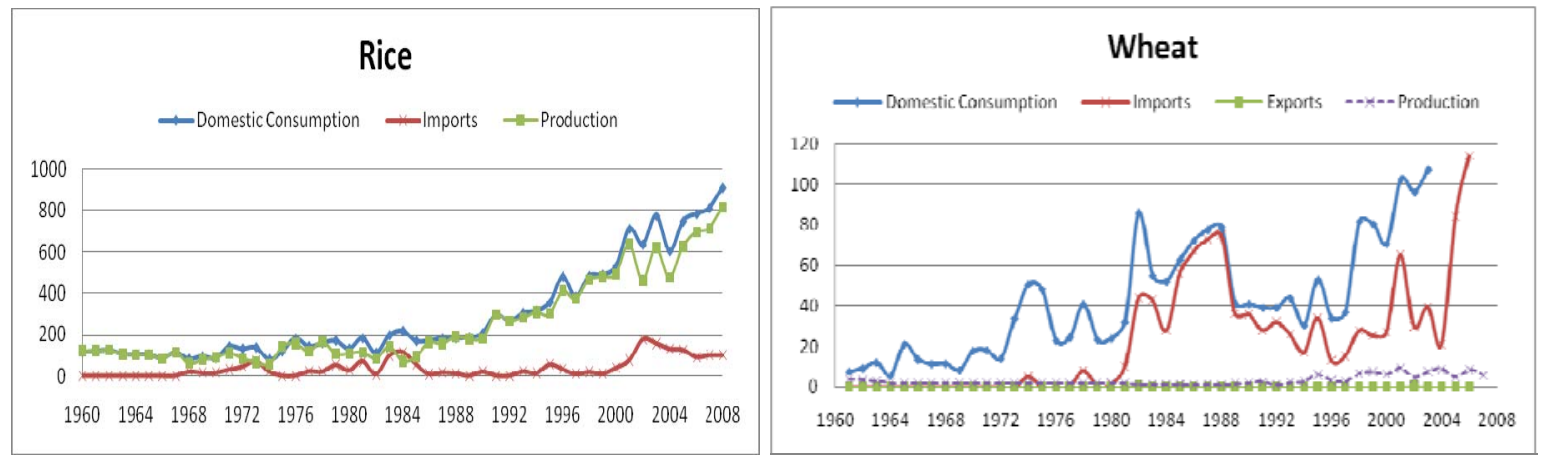

Source: USDA, Foreign Agricultural Service and FAOStat

Table 8 in the appendix also reveals the exposure of the two countries for all agricultural sectors. All these stylized facts describing the dependence of cereal imports for consumption and the structure of trade for agricultural sectors in the two countries are one of the sources of the crossed destinies we will describe in the distributional analysis.

\subsection{Food security in West Africa}

Prices increased in both countries starting in 2006, but the rise was particularly steep in Senegal, with an inflation of four percentage points over the regional average (see Figure 4) in 2007.

Figure 4 : Harmonized inflation rates (\%) in the West African Economic and Monetary Union (WAEMU) countries

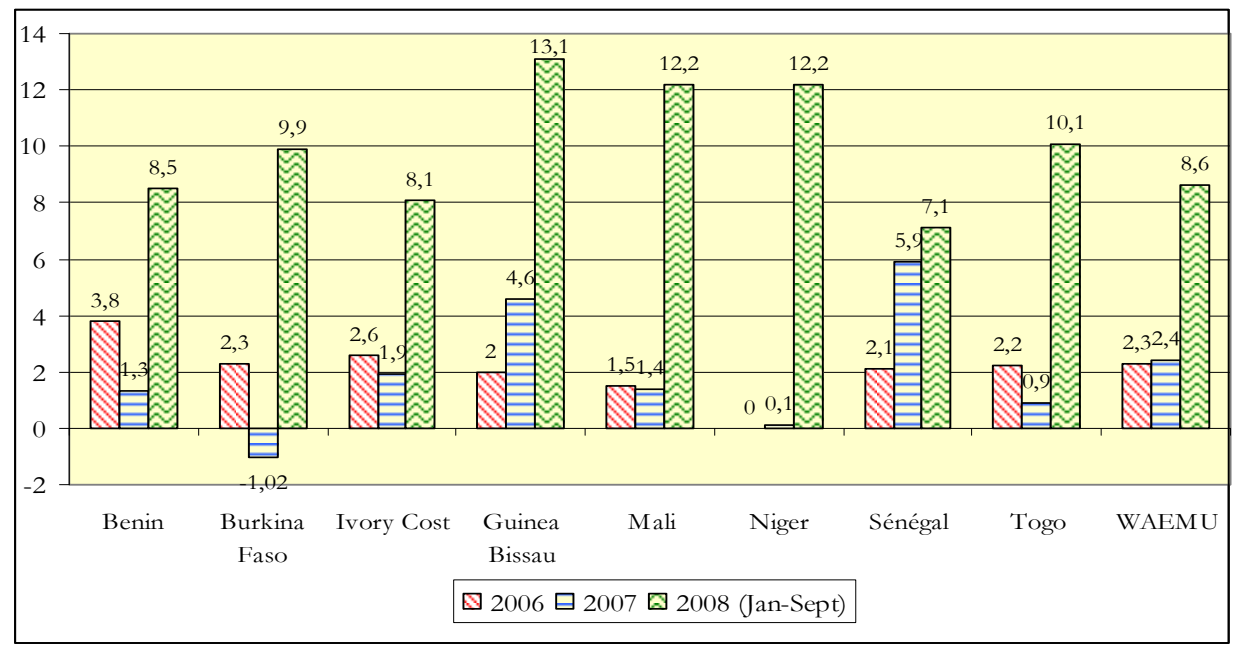

Source: ANSD (2008) and Afristat.

In 2008, while the rise remained around 7\% in Senegal, Mali suffered from considerable inflation in the first eight months of the year (12.2\%). In October 2008, the FAO published a 
report of the food situation in which it observed high and rising food prices that affected consumer purchasing power and reduced access to food in spite of government actions. For example in Senegal, the price of rice in July 2008 was more than double its level a year earlier. In Mali, the price of millet was about $28 \%$ above its level a year earlier (FAO, 2008c).

In Senegal, the inflation rate reached $7 \%$ in 2008 after having oscillated around 3\% for more than a decade. Furthermore, local products significantly contributed to price increases, given their weight in the household consumption basket. This is especially true if we consider that the prices of local goods increased by $6.3 \%$ in 2007 while those of imported products increased by $4.7 \%$. However, this tendency was reversed in the first half of 2008 , reflecting the steep rise in world prices.

In the case of Senegal, Cabral (2008) identified the determinants of food insecurity by taking into account specificities of rural and urban households. He found that farmers who performed subsistence agriculture with livestock breeding were protected from the crisis, whereas farmers performing subsistence agriculture only were most vulnerable. The diversification of production seems to protect households from food insecurity.

The Integrated Regional Information Networks (IRIN) announced in August 2008 that up to 2.1 million Senegalese (out of 11 million) are facing food insecurity linked to high food prices combined with a poor harvest in 2007. Over one million are facing severe food insecurity, and the situation could deteriorate if prices remain high for a prolonged period of time.

In Mali, crop production for the $2007 / 08$ season was 5\% above that of the previous year and $22 \%$ above the five-year average. In addition, conditions in livestock-raising areas across the country are quite favourable, according to the Mali Food Security Outlook 2008 (USAID, 2008). According to USAID (2008), most of the country should not experience major food security problems, even with the rising prices of fuel and food in the sub-region.

The price increases exposed the vulnerability of the populations of these two western African countries. In this context, the Malian and Senegalese governments implemented policy responses to attenuate the negative impact of the crisis.

\subsection{Actions by the governments of Senegal and Mali}

Both governments decided to intervene in order to limit the impact of the increase of food prices on their populations. We describe two types of interventions that were implemented: the 
first consisted of emergency measures to help people respond to the crisis, and the second consisted of a program with a more structural and longer-term perspective.

In March 2008, the Senegalese Statistic and Demographic National Agency (ANSD) formulated recommendations to deal with the impact of petroleum product and food price increases. Their recommendations included the reduction of the fiscal burden for petroleum products and food products, as well as the creation of a surveillance unit to ensure that retailers would not capture the benefits of the fiscal policy instead of transferring them to consumers. To strengthen the agricultural sectors, the Agency suggested diversifying production as well as increasing national added value and exports, thus minimizing the dependence effects of Senegal on outside sources, notably in the field of necessary commodity goods.

In Senegal, the government implemented a food aid program distributing 50,000 MT of rice in rural zones over three months and aiming to distribute $3 \mathrm{~kg}$ of rice per person. The programme seemed to reach its objective, as the government did not declare an emergency food situation ${ }^{4}$. There was also an intense debate over the possible necessity of providing assistance to replenish village cereal banks and improve agricultural training and school feeding programmes. The main proposed measure was to reduce taxes on gas and food products (namely import duties and VAT reductions). The government also put in place a surveillance office to monitor retailer behaviour, in order to prevent price gouging. In addition, the government proposed some tax exemption for major agricultural investment projects, with the objective of reaching self-sufficiency in food production. This was part of the GOANA programme (Grande offensive agricole pour la nourriture et l'abondance) launched in April 2008, which aims to increase production of rice, corn, wheat, and cassava.

In Mali, the food crisis offered an opportunity to implement the agricultural development strategy which was included in the PDES (Social and Economic Development Program), with a focus on rice production. This programme aims to produce a surplus in cereals of over 900 thousand tons in 2012. The other crops concerned are corn, millet, and wheat. For the rice initiative, various actions include irrigation projects, improvement of seed distribution, increased use of new technologies, and implicit subsidies for the most efficient producers. Funding for the rice initiative was confirmed by two agreements in August 2008 between Canada and the

\footnotetext{
4 There was a national debate over the actual situation in the country and the political option of declaring an emergency food situation.
} 
Netherlands ${ }^{5}$. The government of Mali also suspended import duties on wheat and flour from the start of the food crisis until October 2008.

\section{Senegalese and Malian models \\ 3.1 CGE macro-micro modeling}

One of the first contributions linking a CGE model and micro data in a developing country is that of Adelman and Robinson (1978) for South Korea. This application was followed by that of Taylor and Lysy (1979) for Brazil, Dervis et al. (1982). These papers were pioneers in income distribution analysis with CGE models. Later, in the early nineties, de Janvry et al. (1991) analysed the impact of structural adjustment programs on income distribution in Ecuador. They used the Foster, Greer and Thorbecke (FGT) metric (1984) to measure poverty changes. Chia et al. (1994) also used the same indices in a CGE application for the Ivory Coast.

More recently, a new wave of researchers tried to go further by making poverty analysis a central objective of research. As a result, it was possible, in particular, to highlight the relationship between economic policies, poverty levels, and income distribution. These researchers include Decaluwé et al. (1998), Cogneau and Robilliard (2000), and Cockburn (2001). These papers have been followed by a large number of applications ${ }^{6}$.

Three main approaches have been used to link macro reforms to changes in income distribution and poverty. The first and most commonly used one is the representative household approach (RH), the second is usually referred to as the CGE integrated multihousehold (IMH) approach ${ }^{7}$, and the third is generally referred to as the top-down or microsimulation sequential approach (MSS). The RH approach consists of using representative household subgroups in a CGE model and inferring changes in the income of all the households within each group based on the change of income of the representative household of the CGE model. With this approach, the within-group redistribution of income is not taken into account and can lead to misleading conclusions, as demonstrated in Savard (2005). The IMH approach first proposed by Decaluwé et al. (1999) consists of including a large number of households from the household survey or all households of the survey into a CGE model.

\footnotetext{
${ }^{5}$ The funding is up to 3.5 billion FCFA to support the Government of Mali's Rice Initiative.

${ }^{6}$ For an interesting review and discussion on the value of CGE macro-micro approach to analyse poverty and inequality impact, the reader can consult Hertel and Reimer (2004).

${ }^{7}$ Some authors refer to this approach as a CGE micro-simulation application.
} 
However, it can raise some difficulties at the implementation and resolution stage. First, according to Rutherford et al. (2005), data reconciliation can be very problematic; and second, the numerical resolution can be challenging (Chen and Ravallion, 2004).

The third approach is referred to as the CGE micro-simulation sequential method (MSS), This approach is formalized in Chen and Ravallion (2004). The general idea of the MSS approach is that a CGE module feeds market and factor price changes into a micro-simulation household model. We have selected this approach for the two countries since we encountered data reconciliation problems similar to those raised by Chen and Ravallion (2004) for the Malian dataset and to insure comparability of our results. The two models used for the analysis are the same.

Before describing the models in more detail, we should highlight the key transmission mechanisms between exogenous world price changes and household welfare changes. Economic policies or external shocks are generally transmitted to household welfare mainly through variations in the prices of goods and services affecting the cost of consumer baskets and also the prices of production factors. Between the external price shock and internal price changes, a large number of interactions between production sectors are involved in which factors relocate, and relative prices change. Moreover, the structure of the economy and behaviour of agents also play an important role in determining the final outcome. Macroeconomic closure rules and free parameter values could potentially influence results.

\subsection{The Senegalese Model}

We will begin by describing the database we used. The social accounting matrix (SAM) is decomposed into 10 production sectors, seven of which are tradable and three of which are non-tradable based on 1995 data. Specific accounts are used to distinguish between supply by destinations, namely for domestic and export markets. The CGE module includes four agents namely, an aggregate household, the government, firms, and the rest of the world. We have also included savings and investment account. In all, the SAM contains 59 accounts. All 3,278 households of the Enquête sénégalaise auprès des ménages (ESAM I) for 1994/1995 have been integrated into a household microsimulation model.

The macro-micro CGE model used in this paper is a slightly modified version of the one described in Boccanfuso et al. (2009). Without going into great detail, we will present the main 
features of this CGE-model. Using a Cobb-Douglas production function (for value-added), we assume producers have a cost-minimizing behaviour constrained by this production function. Value-added is a combination of capital and labour and is related to intermediate consumption with fixed-share assumption. Capital is assumed to be fixed, which generates a branch-specific return on capital. The returns on capital combined with the wage provide for ten factor payments. These factors payments are the main source of the heterogeneous impact on household income changes. This assumption implies that a short-to-medium-term perspective is taken, for time is needed to move capital from one sector to another following a real-life policy shift. The government collects its revenues through income taxes imposed on households and firms), goods and services taxes, import duties, and transfers from other agents (the rest of the world). It spends this revenue by paying subsidies and by producing public services. Household income is composed of wage payment, capital payments, dividends, and transfers from other agents (households and remittances from abroad).

Household expenditure is derived from maximizing a Cobb-Douglas utility function under budgetary constraint. The income tax rate corresponds to the effective tax rate and not the administrative rate $^{8}$. The welfare indicator used at the household level is the real income. The nominal income is deflated by a household-specific consumer price index ${ }^{9}$. This approach is different than the endogenous poverty line approach proposed by Decaluwé et al. (2005), as it captures a household-specific price effect of the simulation based on each household consumption structure.

As for closure rules, we also assume that government saving is exogenous and that total investment is endogenous, since its level is determined by the level of savings (domestic and foreign). The fixed total labour supply is assumed and workers can move from one sector to another following a simulation. Hence, there is no endogenous unemployment in the model ${ }^{10}$. The current account balance $(\mathrm{CAB})$ is exogenous, as well as the nominal exchange rate which also serves as the numéraire. The price index (GDP deflator) is endogenous and allows for

\footnotetext{
8 This holds for all tax rate levels. Modelling taxes in such a way allows us to be coherent with the observed data and implicitly integrates all forms of tax exemptions and evasions into the model.

${ }_{9}$ In our simulations, we compared results obtained from this approach with those obtained using the equivalent variation to measure the change in welfare at the household level. The results obtained from the two approaches were not significantly different and hence we can say the results presented are robust to this choice.

10 This does not mean that we assume there is zero unemployment in the Malian economy, but simply that unemployment is exogenous to the model.
} 
clearing the CAB. We assume in a standard fashion that Senegal is a small open economy with the Armington (1969) assumption for the demand of imported goods: imperfect substitution with constant elasticity of substitution function (CES) and constant elasticity of transformation functions (CET) to model the export supply ${ }^{11}$.

The distributional analysis is performed from an output originating from the micro simulation household module but including 3,278 households. We transmit price changes and factor payment changes from the CGE module to the micro module in a top-down fashion. With these new prices, the module computes the new incomes and household specific price indices. The price indices are a function of each household expenditure structure. The output of the micro module is a vector of new real income.

\subsection{The Malian Model}

For Mali, we used an input-output table containing 17 production branches for 2001 as a starting point to construct the social accounting matrix (SAM) and aggregate to obtain 12 production branches, and used secondary data sources to complete the SAM with an inputoutput table. This was quite convenient in terms of timing, as a national household survey was performed during the same year. The Malian household survey "Enquête malienne d'évaluation de la pauvretê" (EMEP) is a very rich database in some ways. It contains 4,966 households. The model used here is similar to that of Boccanfuso et al. (2008). As the models are the same for the two countries, we will not reiterate the presentation of the model. As for the Senegalese model, the distributional analysis is performed from an output originating from the micro module but including 4,966 households. The closure rules are identical in the two models.

\section{Simulations}

In our analysis, we perform four simulations for each country. The most important simulations are the first two, which reproduce the impact of the food crisis linked to the increase in world prices of agricultural goods. The last two simulations aim to investigate the distributional impact of two potential responses that governments can and have implemented in the two countries to respond to the food crisis. Following is a more detailed description of our choice of simulations.

\footnotetext{
${ }^{11}$ CGE models are generally not stochastic in nature.
} 
In this first simulation, we did not specify the agricultural goods affected by world price increases. We selected an increase of $70 \%$ for this simulation. It is not the exact weighted average of price increases observed in the last year, but this is irrelevant, as we do not attempt to reproduce what happened last year but to compare a similar external impact on two comparable countries. The exact level selected for this and other simulations is quite irrelevant, insofar as our main focus is to compare the impact on two countries ${ }^{12}$.

For this second simulation, we wanted to focus on the increase of price for cereals and since the two countries agricultural exports are mainly crop agriculture (Cotton for Malian and groundnut and cotton for Senegal) we simulated an increase in world price of agricultural imports only. As showed in Table 7, cereal imports are extremely important in Senegal and have been a major concern of the Senegal government for many years. Mali also imports $8 \%$ of its total agricultural consumed goods but a weight much lower compared to $23 \%$ in Senegal (see Table 8 in appendix).

For our third and fourth simulation, we apply to responses to the food crisis observed in the two countries. In the third simulation, we simulate a land reform policy which provides increased access to land for potential farmers in the country. In Senegal, this was done through the GOANA program, in which each municipality had to supply some land to interested and capable farmers. This policy created an expansion of land use for agricultural production. This can be captured by increasing the capital in the agricultural sector the models, as land represents the main part of the agricultural capital. We simulate an increase of $30 \%$ in capital in the agricultural sector jointly with the first simulation.

The final simulation that we perform (simulation 4) was applied in the two countries. This is a temporary elimination of import duties on cereals. We performed this simulation jointly with the second simulation, which concerns the world prices of cereals.

\section{Results}

\subsection{Macro and sectoral impacts}

This section will be brief as it is not the focus of our paper but is essential in presenting the main results, as well as the impact on prices and on factor payments. These are key variables in

\footnotetext{
12 Moreover, we do not have data for the same year for the two countries. Without going into detail on our results, we checked for stronger and weaker impact and our general conclusions which will be presented herein were robust to the different levels of the simulations (between 60 and 90\% increase in world price).
} 
modifying household welfare following the price changes and policy measures which absorb part of the negative impact of the food crisis. We will also concentrate on the comparative analysis between the results of the two country models. Some key macro results will be dealt with before we move on to price and factor payment changes. The macro results for both countries are presented in the following table (Table 1). It is important to highlight that we present the real (and not nominal) values of the variables. This conversion is important since our price index is endogenous.

Table 1: Macro results for Senegal and Mali

\begin{tabular}{|c|c|c|c|c|c|c|c|c|c|c|}
\hline \multicolumn{11}{|c|}{ Macro results results (\% variations) } \\
\hline & \multicolumn{5}{|c|}{ Senegal } & \multicolumn{5}{|c|}{ Mali } \\
\hline Variables & Reference & Sim 1S & Sim $2 S$ & Sim 3S & Sim 4S & Reference & Sim 1M & Sim 2M & Sim 3M & $\overline{\mathrm{Sim} 4 \mathbf{M}}$ \\
\hline Agg. household income & 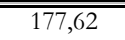 & 0,60 & 0,67 & 2,48 & 0,11 & $\overline{149,55}$ & 1,15 & 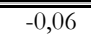 & 0,08 & $\overline{-0,11}$ \\
\hline Wage & 1,00 & $-1,30$ & $-1,81$ & $-3,20$ & $-4,60$ & 1,00 & $-1,41$ & 0,08 & 9,54 & $-1,07$ \\
\hline Government income & 59,41 & 3,13 & 3,67 & 5,07 & $-0,55$ & 30,74 & $-4,30$ & 0,43 & 3,74 & $-1,77$ \\
\hline Public expenditure & 29,46 & 0,92 & 0,70 & 3,31 & $-8,09$ & 25,60 & $-2,86$ & 0,41 & 7,31 & $-2,42$ \\
\hline Total investment & 101,12 & 1,95 & 2,55 & 2,57 & 3,51 & 49,28 & $-4,33$ & 0,24 & 14,08 & 0,49 \\
\hline GDP & 213,63 & $-0,02$ & 0,04 & 1,36 & 0,04 & 181,94 & 0,21 & 0,000 & 5,219 & 0,001 \\
\hline Price index & 1,00 & $-5,05$ & $-6,19$ & $-6,37$ & $-6,43$ & 1,00 & 12,95 & $-0,55$ & 16,31 & $-1,42$ \\
\hline
\end{tabular}

The first general observation we can make is that the amplitude of the effects is stronger in Senegal than in Mali except for the first simulation. This is a result of the importance agricultural trade in Senegal compared to Mali. The second observation is that in all scenarios, the aggregate household real income improves in the two countries for all simulations except simulation 2 and 4 for Mali. The third general observation is in regards to government income, which increases in all scenarios in Senegal but simulation 4 and decreases in two out of four simulations in Mali.

Comparing the first simulation between the two countries, we observe a similar impact on aggregate household real income and the wage, but an opposite effect on government income and expenditure, on total investment, and on the price index. The differentiated effects originate mainly from the trade structures of agricultural goods in the two countries. Other structural differences between the economies also contribute to these differences to a lesser extent. It is interesting to note the major difference observed for the variation of the effect on the price index. In fact, one needs to keep in mind that this variable needs to adjust to balance out the current account balance. In Senegal, a depreciation of the real exchange rate is required where a real exchange rate appreciation is necessary in Mali. The importance of cotton exports and the structure of Senegal exports help explain these differences. 
Comparing this with the second simulation provides interesting results. In fact, when only import prices are affected, the impact is stronger in Senegal and becomes very weak in Mali. The import/export structure presented in Table 8 is the main explanation for these different effects. For the third simulation, we observe an improvement in government income in both countries, an improvement in household real income in Senegal, and a decrease from the first simulation in Mali. For this simulation, the pressure on the real exchange rate is in the same direction as in other simulations, but the pressure is stronger in both countries. For the last simulation, the comparison with Simulation 2 reveals deterioration for the aggregate households and governments in Senegal and Mali. This last effect is not surprising, since the elimination of import duties directly reduces the government's income. When comparing simulation 2 and 4 in Mali, we note very little change at the household level.

From these macro results, we could conclude to improvement of the situation for households in the two countries (or slight negative impact in Mali for two simulations). However, these macro results hide the distributional impact which occurred following these simulations. The sectoral results will start giving some clues as to these distributional effects, but will not be sufficient to draw conclusions. We will only present market price changes (Table 2) and variations in the rental rate of capital (Table 3), as these are key variables for the distributional impact analysis.

The first simulation produces a relatively strong impact on domestic prices of agricultural goods in Senegal (+15.59\%). The situation is somewhat different in Mali, as the price increase is much smaller $6.13 \%$. This is related to the importance of agricultural imports for Senegal (see Table 8$)^{13}$. When we compare the first two simulations, we observe that the situation is very similar in Senegal, where in Mali, the effect is much weaker in the second simulation. For the third simulation, the increase in supply by the agricultural sector tied to the increase in land use reverses the price effect on the agricultural sectors in Mali, but only attenuates the strong positive effect on the agricultural price in Senegal (compared to Simulations $1 \mathrm{~S}$ and 2S). The fourth simulation seems to play its role of shock absorption for agricultural sector prices in Senegal but the price increases more in Mali.

\footnotetext{
13 It is important to keep in mind that these prices are real prices and the change in price index produces an opposite effect in the two countries. It is also important to analyse the price changes in relative terms between each sector.
} 
Table 2: Market price variations for Senegal and Mali

\begin{tabular}{|c|c|c|c|c|c|}
\hline \multicolumn{6}{|c|}{ Market price results (\% variations) } \\
\hline \multicolumn{6}{|c|}{ Senegal } \\
\hline Branches & Reference & Sim 1S & $\operatorname{Sim} 2 S$ & Sim 3S & $\operatorname{Sim} 4 \mathrm{~S}$ \\
\hline Agriculture & 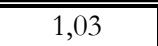 & 15,59 & 14,53 & 9,75 & 10,29 \\
\hline Livestock & 1,00 & 1,53 & 0,83 & 1,65 & 1,22 \\
\hline Fishing & 1,00 & $-0,98$ & $-2,67$ & 2,91 & $-1,77$ \\
\hline Edible oil industry & 1,18 & 9,21 & 8,13 & 5,66 & 5,13 \\
\hline Other food industry & 1,10 & 2,62 & 1,86 & 2,44 & 1,44 \\
\hline Mining industries & 1,01 & 5,23 & 5,24 & 5,10 & 5,28 \\
\hline Ohter manufacturing & 1,13 & 3,73 & 3,35 & 3,83 & 3,16 \\
\hline Commerce & 1,02 & $-1,98$ & $-4,07$ & 7,16 & $-0,93$ \\
\hline Ohter services & 1,01 & 1,74 & 0,88 & 1,91 & $-0,15$ \\
\hline Public services & 1,00 & 0,20 & $-1,09$ & $-1,73$ & $-3,19$ \\
\hline \multicolumn{6}{|c|}{$\overline{\text { Mali }}$} \\
\hline Branches & Reference & Sim $1 M$ & $\operatorname{Sim} 2 \mathrm{M}$ & $\operatorname{Sim} 3 \mathbf{M}$ & $\operatorname{Sim} 4 M$ \\
\hline Agriculture & 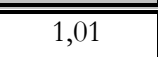 & 6,13 & 2,54 & $\overline{-12,81}$ & 3,50 \\
\hline Fishing and livestock & 1,01 & $-1,95$ & 0,09 & 0,63 & 0,17 \\
\hline Forestry & 1,00 & $-0,62$ & 0,03 & 1,41 & 0,11 \\
\hline Mining industries & 1,00 & $-9,11$ & 0,45 & $-5,83$ & 1,10 \\
\hline Food industries & 1,11 & $-4,16$ & 0,25 & $-3,14$ & 0,75 \\
\hline Other manufacturing & 1,15 & $-10,02$ & 0,49 & $-10,51$ & 1,19 \\
\hline Construction & 1,02 & $-4,57$ & 0,23 & 2,22 & 0,06 \\
\hline Commerce & 1,02 & $-0,20$ & 0,03 & 2,20 & $-0,08$ \\
\hline Other services & 1,04 & $-2,93$ & 0,16 & 5,30 & $-0,40$ \\
\hline Public services & 1,00 & $-3,11$ & 0,18 & 3,96 & $-0,41$ \\
\hline
\end{tabular}

The rental rate of capital plays an important role on the households' income side. A large portion of households draw part or most of their income from this source. Significant change in these prices will have a strong impact on these households. Results are presented in Table 3.

The impact in the two countries for the rental rate of capital is different for Simulation 1. This is a consequence of the import and export structure from these sectors. In Senegal, a large portion of agricultural goods are not exported directly but transformed into edible oil. Hence, producers cannot directly exploit this market to increase their income. In Mali, the cotton sector, which exports most of its production, strongly benefits from the world price increase.

In the second simulation, we observe a slightly negative situation in the agriculture, food industries and textile sector in Mali. Other sectors in Mali exhibit small positive change in rental rate of capital. In Senegal, the decrease is stronger for the agricultural and commerce sectors 
compared to Simulation 1S. However, most other sectors seem to perform better in this simulation compared to Simulation 1.

Table 3: Rental rate of capital variations for Senegal and Mali

\begin{tabular}{|c|c|c|c|c|c|}
\hline \multicolumn{6}{|c|}{ Rental rate of capital results ( $\%$ variations) } \\
\hline \multicolumn{6}{|c|}{ Senegal } \\
\hline Branches & Reference & Sim 1S & Sim $2 S$ & Sim 3S & Sim 4S \\
\hline Agriculture & 1,03 & "-8,88 & $-12,15$ & $-40,13$ & $-11,11$ \\
\hline Livestock & 1,00 & 1,52 & 2,40 & 1,27 & 2,72 \\
\hline Fishing & 1,00 & 5,32 & 7,20 & $-2,89$ & 3,83 \\
\hline Edible oil industry & 1,18 & $-24,79$ & $-21,57$ & $-9,23$ & $-9,91$ \\
\hline Other food industry & 1,10 & 2,18 & 3,95 & 1,88 & 4,26 \\
\hline Mining industries & 1,01 & 8,59 & 10,85 & 9,05 & 11,76 \\
\hline Ohter manufacturing & 1,13 & 6,67 & 8,74 & 3,92 & 7,78 \\
\hline Commerce & 1,02 & $-4,63$ & $-6,48$ & 13,35 & 0,31 \\
\hline Ohter services & 1,01 & 1,33 & 1,79 & 3,79 & 1,21 \\
\hline \multicolumn{6}{|c|}{$\overline{\text { Mali }}$} \\
\hline Branches & Reference & $\overline{\operatorname{Sim} 1 \mathrm{M}}$ & $\overline{\operatorname{Sim} 2 M}$ & $\overline{\operatorname{Sim} 3 M}$ & $\overline{\operatorname{Sim} 4 M}$ \\
\hline Agriculture & $\bar{~} 1,01$ & $\overline{15,87}$ & 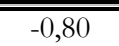 & $\overline{-6,33}$ & $\overline{0,16}$ \\
\hline Fishing and livestock & 1,01 & $-3,20$ & 0,15 & $-1,86$ & 0,45 \\
\hline Forestry & 1,00 & $-1,16$ & 0,06 & $-0,06$ & 0,30 \\
\hline Mining industries & 1,00 & $-16,47$ & 0,79 & $-23,30$ & 2,38 \\
\hline Food industries & 1,11 & $-1,40$ & $-0,13$ & 1,14 & $-1,88$ \\
\hline Other manufacturing & 1,15 & $-6,45$ & 0,34 & 4,95 & 0,79 \\
\hline Construction & 1,02 & $-0,90$ & 0,08 & 26,31 & $-0,52$ \\
\hline Commerce & 1,02 & 0,34 & 0,00 & 1,42 & $-0,01$ \\
\hline Other services & 1,04 & $-2,11$ & 0,15 & 10,00 & $-0,45$ \\
\hline
\end{tabular}

Simulation 3 produces a strong negative effect on the agricultural sector in both countries. In Senegal, the exports are constrained by the limited capacity to export their agricultural products which forces producer to sell on the local market and a strong drop in price is required to balance out the market. However, for Mali this constraint is not as strong and it can increase its exports to the rest of the world resulting in a lower decrease in rental rate of capital for agriculture. Finally, the removal of import duties (simulation 4) compared to Simulation 2 improves the situation in agricultural sectors for both countries. The edible oil sector in Senegal benefits the most from this policy option (4S compared to $2 \mathrm{~S}$ ), and in Mali the mining sector benefits the most from outside agriculture.

As previously stated, these results reveal some similarities, but some effects are different at the macro and sectoral levels. We cannot draw distributional conclusions solely from these results. In this analysis, we do not capture the price effect from the consumption side and we do not 
capture the different income and expenditure structures for poor households or households with specific characteristics.

In the next section, we proceed with the micro impact analysis of the four simulations for Senegal and Mali. We applied the FGT poverty indices and their variation, followed by the inequality analysis with the Gini index. Finally, a pro-poor growth analysis based on various indices and graphical tools was carried out to evaluate the impact of the simulations.

\subsection{Distributional impacts}

Changes in returns on factors and prices of goods and services do not affect households in a uniform way, since their income and expenditure structures are different. It is important to evaluate impacts of shocks on poverty and inequality, taking into account heterogeneity at the household level. For each country, we identified three household groups according to their geographical location, namely the capital (Dakar and Bamako), the other urban areas, and the rural areas ${ }^{14}$. Most of the population lives in rural areas, with $70.92 \%$ and $57.57 \%$ respectively for Mali and Senegal. These rural households depend on subsistence agriculture and livestock rearing. Whereas in Mali the second biggest group are in urban centers other than the capital $(19.92 \%)$, nearly a quarter of the Senegalese population is based in Dakar $(23.47 \%)$. The variation in mean incomes for each simulation and group is reported in Table $4^{15}$.

Table 4 : Group proportions and variation of mean real income

\begin{tabular}{|c|c|c|c|c|c|c|}
\hline & & Proportion & $\operatorname{Sim} 1$ & $\operatorname{Sim} 2$ & $\operatorname{Sim} 3$ & $\operatorname{Sim} 4$ \\
\hline \multirow{4}{*}{ Mali } & Country & $100.00 \%$ & $0,60 \%$ & $1,73 \%$ & $-10,46 \%$ & $-0,56 \%$ \\
\hline & Bamako & $11.16 \%$ & $3,54 \%$ & $0,81 \%$ & $-3,74 \%$ & $0,56 \%$ \\
\hline & Other urban & $17.92 \%$ & $-3,02 \%$ & $-0,93 \%$ & $5,33 \%$ & $-0,60 \%$ \\
\hline & Rural areas & $70.92 \%$ & $3,51 \%$ & $-1,34 \%$ & $16,06 \%$ & $-0,55 \%$ \\
\hline \multirow{4}{*}{ Senegal } & Country & $100.00 \%$ & $-0,37 \%$ & $-0,75 \%$ & $2,37 \%$ & $0,24 \%$ \\
\hline & Dakar & $23.47 \%$ & $5,13 \%$ & $4,91 \%$ & $5,31 \%$ & $5,05 \%$ \\
\hline & Other urban & $18.96 \%$ & $-0,17 \%$ & $-0,36 \%$ & $1,45 \%$ & $0,51 \%$ \\
\hline & Rural areas & $57.57 \%$ & $-6,22 \%$ & $-6,89 \%$ & $-0,11 \%$ & $-4,95 \%$ \\
\hline
\end{tabular}

\footnotetext{
${ }^{14}$ This classification of household is independent of the CGE models, as all households are included directly or sequentially in both models.

15 These are weighted means computed from the micro household data and not from the CGE aggregate household results.
} 
The simulation 1 produced a decrease in mean real income at the national level in Senegal and an increase in Mali. The only group positively affected in Senegal are Dakar households and the only negatively affected in Mali are the other urban households. For Senegal, this average change is contrary to the change in real income for the aggregate household income computed from CGE model.

The second simulation is different at the national level with an improvement in Mali and a negative impact in Senegal, but at the group level we have similar effects with positive impact on the capitals and negative effect on other groups with strongest negative impact on rural households. The qualitative effect of simulation 3 is reversed for all cases except for other urban dwellers who are winners in both countries. When we applied the elimination of agricultural import duties (Simulation 4), the only group benefiting in Mali are the residents of Bamako when in Senegal the two urban groups gains from the removal of import duties. The last general observation concerns the negative impact on average income of four simulated shocks and policies for the rural Senegalese group. The smallest decrease is observed in Simulation 3 where mean income for this group decreased by $0.11 \%$. However, the same simulation in Mali generates a rise of $16.06 \%$ for the same group. The difference in the two countries comes from the large volume of cotton export in Mali, which significantly prevents the decrease of the aggregate rental rate of capital for agriculture, as is observed in the agricultural sector in Senegal.

The approaches used for poverty and inequality analysis are similar to those used in the context of micro simulation CGE models and poverty. After identifying the target groups for the reference period, the next step is to compute and compare poverty and inequality indices. The poverty index is the Foster, Greer and Thorbecke (FGT, 1984) ${ }^{16}$ index and for inequality we

${ }^{16}$ FGT poverty indexes are additively decomposable; as such they are interesting in the framework of this analysis and make it possible to measure the proportion of the poor among the population, as well as poverty depth and severity. They are calculated using the following equation:

$$
F G T_{\alpha}=\sum_{i=1}^{q}\left(\frac{z-y_{i}}{z}\right)^{\alpha}
$$

where $\alpha$ is a parameter characterizing the degree of poverty aversion; $z$, the poverty line; $y_{i}$, household income; and $q$, the number of poor households, in other words, below the poverty line. Generally, the higher $\alpha$ is, the greater the importance granted to the poorest (Ravallion, 1994). 
use the $\mathrm{Gini}^{17}$ index. In addition to these indices, we applied pro-poor growth analysis for the two policy scenarios (Simulations 3 and 4). Table 5 describes poverty analysis for the reference period for both countries and each regional group. From this table, we respectively observe $61.38 \%$ and $68.26 \%$ poverty rates for Senegal and Mali. Rural regions exhibit the highest poverty incidence, particularly in Mali, where more than $80 \%$ of households are poor.

Table 5 : Poverty indices for Senegal and Mali (\%)

\begin{tabular}{|c|ccccc|cccc|}
\cline { 3 - 9 } \multicolumn{2}{c|}{} & \multicolumn{4}{c|}{ SENEGAL } & \multicolumn{4}{c|}{ MALI } \\
\cline { 2 - 10 } \multicolumn{2}{c|}{} & Country & Dakar & $\begin{array}{c}\text { Other } \\
\text { urban } \\
\text { centers }\end{array}$ & $\begin{array}{c}\text { Rural } \\
\text { area }\end{array}$ & Country & Bamako $\begin{array}{c}\text { Other } \\
\text { urban } \\
\text { centers }\end{array}$ & $\begin{array}{c}\text { Rural } \\
\text { area }\end{array}$ \\
\hline \multirow{3}{*}{ reference } & FGT0 & 61.38 & 49.68 & 62.56 & 65.91 & 68.26 & 27.56 & 36.56 & 80.91 \\
& FGT1 & 27.28 & 21.40 & 27.19 & 27.54 & 30.99 & 8.14 & 11.85 & 39.94 \\
& FGT2 & 15.32 & 11.96 & 15.40 & 14.72 & 19.02 & 3.8 & 5.74 & 24.08 \\
\hline
\end{tabular}

Source: Computed by authors from ESAM I and EMEP with DASP package ${ }^{18}$

As for Dakar, $49.68 \%$ of households residing there are poor, whereas less than $28 \%$ of households are poor in Bamako. The larger portion of residents in the Senegalese capital could explain this difference. Finally, the other Senegalese urban centers are poorer than those of Mali.

We will now analyze the poverty impact of the four simulations at the national level and on each group for both countries. The variations of poverty incidence (FGT0) are presented in Figure 5. We provide more detailed results in Table 10 of the appendix for the poverty depth and severity variations. We generally observe significant differences in both countries, particularly when groups are taken into account. We have a good illustration of this when we compare the capital dwellers and other urban center dwellers for all simulations but the third one. In Senegal, we have a positive impact with a decrease of poverty for both groups, whereas for Mali, we have an increase for the two groups for the three simulations. In Mali, the only simulation reducing poverty for the two urban groups is the third one.

${ }^{17}$ In the Gini index, G measures the distance between Lorenz's curve and perfect equality. G shows the degree of concentration of the distribution of standards of living. His expression is:

$$
G=\frac{1}{2 n^{2} \bar{y}} \sum_{i=1}^{n} \sum_{j=1}^{n}\left|y_{i}-y_{j}\right|
$$

where $\mathrm{n}$ is the size of population, $y_{i}$, household income, and $\bar{y}$ the mean income.

18 The DASP package is freely distributed and freely available (See Araar and Duclos, 2007). 
Figure 5 : Impacts on poverty incidence by groups $(\Delta \%)$

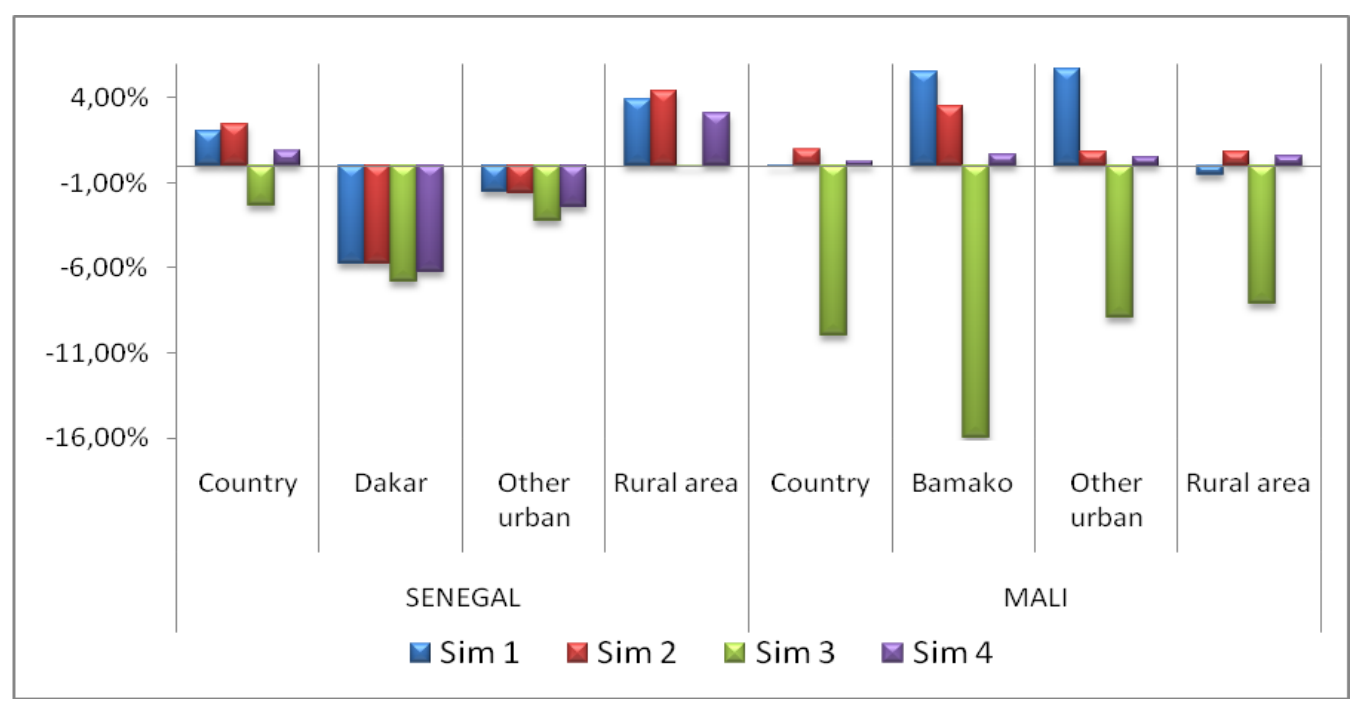

Source: Computed by authors from ESAM I and EMEP with DASP package.

This third simulation is strongly positive in Mali for all groups and is only favourable for the two urban groups in Senegal. For this same simulation, the rural Malian group benefited the least from the policy (8.08\%), compared to urban groups, especially Bamako, with a fall of $16 \%$. The results for Senegal are quite different for rural households, insofar as we observe a stable situation in poverty rate ${ }^{19}$. This result can be attributed to different factors, but the main one is that the gains from the increase in land use and its associated increase in factor endowment was cancelled out by the strong decrease in capital payment in the sector and, as we have previously explained, this is a result of the low level of exports of Senegalese agricultural goods.

The difference in impacts of world price increases (Simulations 1 and 2) between both countries is stronger and significant for the decomposition analysis (group level), albeit for Simulation 1, results are reversed in the two countries for all three poverty indices (see Table 10 in appendix) at the national level and for all groups. For Simulation 2, the qualitative impact is the same at the national level, but twice to three times stronger in Senegal. At the group level, for the second simulation, for Senegal, the external shock is positive for both urban groups, with a reduction of poverty rate and an increase for the rural group when in Mali all groups are negatively affected. The Malian rural households not significantly concerned by the price increases, as opposed to the Senegalese households, which are the most affected by the world

${ }_{19}$ The reduction of poverty is not significant at the $5 \%$ level (see Table 10). 
price increase for agricultural goods (Simulation 2). One explanation for this result is linked to the figures presented in Table 7 and Table 8 in appendix.

For simulation 4, the difference between both countries is similar to the results obtained with simulation 2, but the gap between the two countries is reduced. However, this policy seems to have less effect in Senegal for households in the capital compared to Bamako when we observe a similar positive effect for other urban households between the two countries. This policy has a positive effect in the two countries for all groups, although it is not sufficient to reverse the negative effects observed in both countries.

This analysis revealed that the two West African countries do not suffer from the external shocks in the same way. The negative impact is higher for urban Malian households, although the rural Senegalese are suffering the most from the price increase. Furthermore, the policies simulated to compensate these negative shocks seem to be more efficient in Mali compared to Senegal. We performed pro-poor analysis (presented below) to provide a clearer picture of two targeted policies.

But before dealing with the pro-poor analysis, we will complete our distributional analysis of the food crisis with the presentation of variations in the inequality indices. Comparing the inequality for both countries at the reference period, we observe that Senegal is more unequal compared to Mali with respective Gini indices at 0.48 and 0.40 (Table 6).

Table 6 : Impacts on inequality $(\Delta \%)$

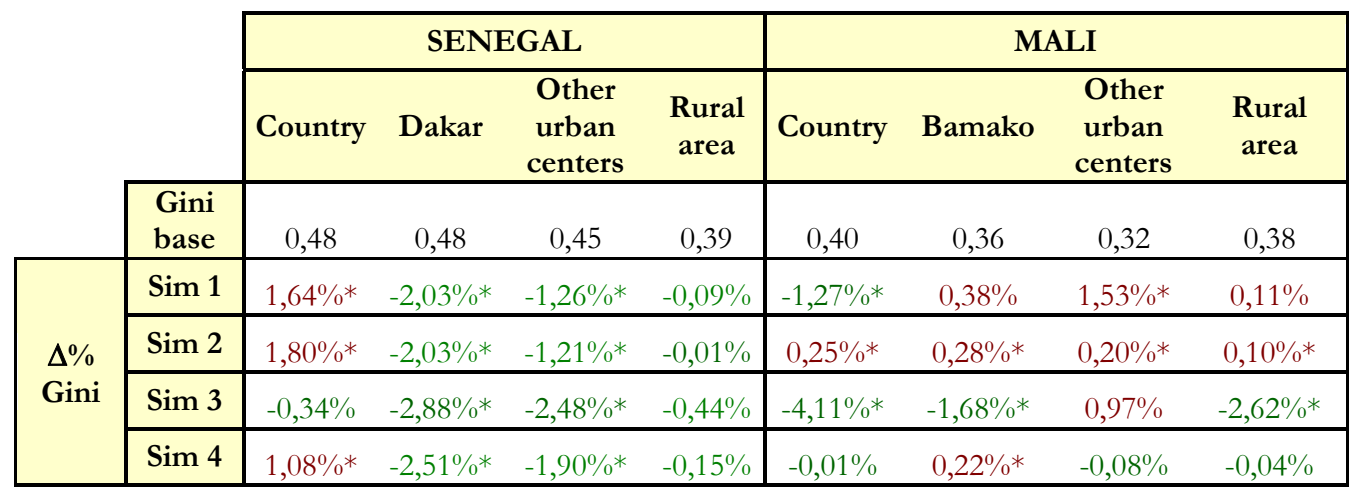

Source: Computed by authors from ESAM I and EMEP with DASP package. * Significant at 5\%.

This is also valid at the group level except for the rural groups, for which the inequality is almost the same in the two countries. Furthermore, while the inequality is stronger in Senegalese urban areas, the rural region is the most unequal in Mali.

The inequality changes for Simulation 1 produced higher inequality for Senegal $(1.64 \%)$ as opposed to a decrease of $-1.27 \%$ for Mali. However, the simulation reduced inequality in the 
Senegalese capital and increased it for other Malian urban centers. The effects on the other groups are insignificant in Mali. For simulation 2, inequality increased in both countries, but with a much stronger increase in Senegal. When the simulation 1 is associated with a rise of agricultural capital (Simulation 3), the impact is positive (reduction in inequality) and significant for Malian households except for the other urban centers group, which suffers from an increase in inequality $(+0.97 \%)$. This policy appears to be an interesting measure for Mali. In this country, the other policy (Simulation 4) only slightly reduces inequality at the national level, but deteriorates the situation for capital city dwellers and is insignificant for the other two groups.

In Senegal, both policies measures had comparable effects at the group level with insignificant results for both simulations in the rural area. However, at the national level, we have an increase in inequality for simulation 4 and an insignificant change for simulation 3 . The last simulation dampens the negative effect at the national level compared to simulation 2 in Senegal.

\subsection{Pro-poor growth analysis of the Goana like programme}

In what follows, this change is described by the growth incidence curve (GIC) developed by Ravallion and Chen (2003). This curve shows the changes in real income by percentile of households before and after policy. To complete the pro-poor analysis, three indices have been computed: the pro-poor growth index (PPGI) of Kakwani and Pernia (2001), the poverty equivalent growth rate (PEGR) of Kakwani and Son (2002), and the absolute rate of pro-poor growth of Ravaillion and Chen (2003) derived from the GIC ${ }^{20}$.

As we previously described, the increase of land use to respond to the food crisis reduced poverty for both countries and all groups. For Mali, the decrease, which is higher for urban areas, could lead one to believe that the growth generated by the increase of capital is more beneficial to the richest groups. However, the growth incidence curve (GIC) drawn for Mali shows that this policy is pro-poor (Figure 6a). This result is confirmed by the three usual absolute and relative pro-poor indices (Table 11).

${ }^{20}$ For a detailed presentation of these indices, see Boccanfuso and Ménard, 2008. 
Figure 6 : Growth incidence curve for (a) Mali and (b) Senegal (Simulation 3)

(a) Mali

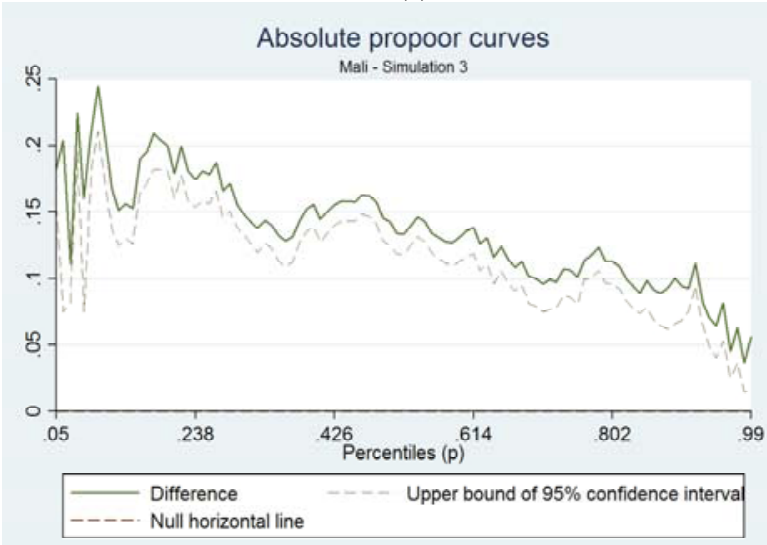

(b) Senegal

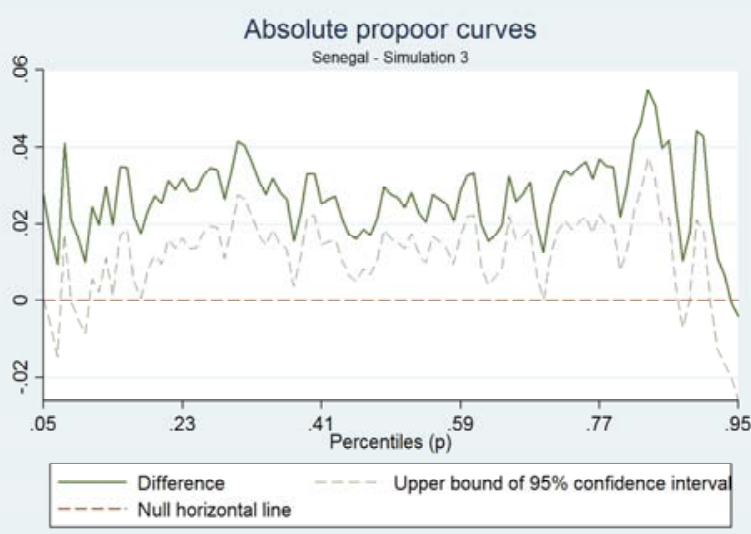

Source: Computed by authors from ESAM I and EMEP with DASP package.

For Senegal, results are different, even if this simulation reduced poverty at the national level $(-2.32 \%)$. In this case, the pro-poor analysis is less clear, since the GIC shows a slightly pro-rich growth, whereas the three indices tend to point to pro-poor growth policy. The most important difference between Mali and Senegal in terms of pro-poor analysis for Simulation 3 concerns the rural households (Figure 7).

Figure 7 : Growth incidence curve for rural areas in (a) Mali and (b) Senegal (Simulation 3)

(a) Mali

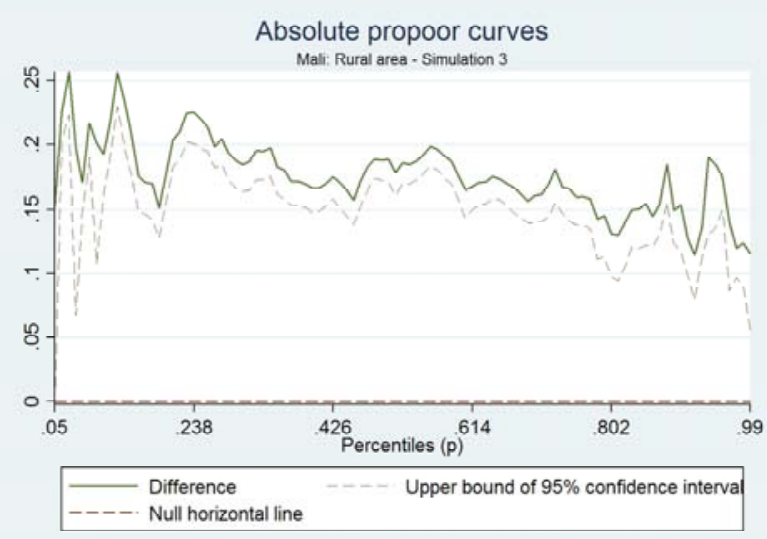

(b) Senegal

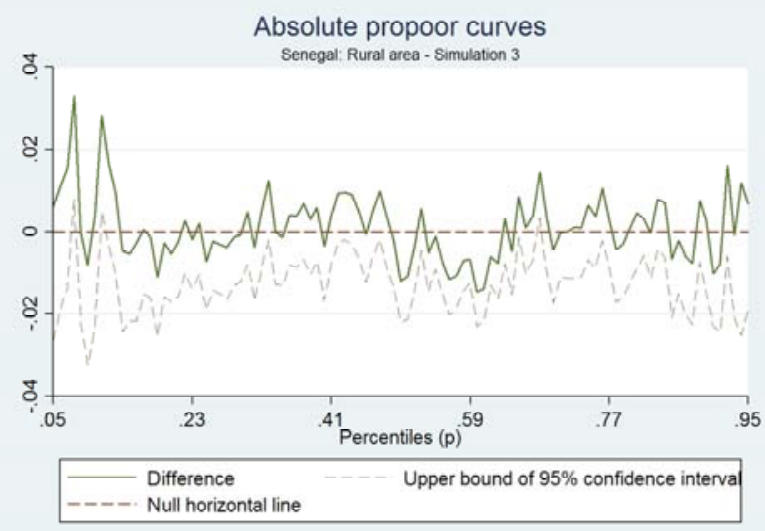

Source: Computed by authors from ESAM I and EMEP with the DASP package.

This difference is caused by the mean income contraction undergone by Senegalese rural households. While the growth of mean income in Mali generated by the policy seems to be pro-poor for the rural households, no clear evidence emanates for the Senegalese rural households. 
At the national level, the pro-poor analysis performed with Simulation 4 shows the difference between both countries, as was the case with the poverty analysis (Figure 8). For the Malian households, the first percentiles have slightly higher income growth compared to rest of the population but the GIC is close to horizontal.

Figure 8 : Growth incidence curve in (a) Mali and (b) Senegal (Simulation 4)

(a) Mali

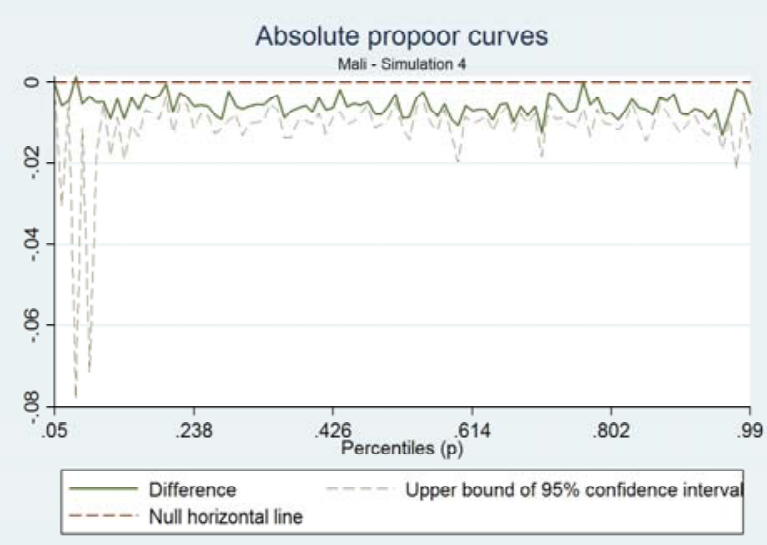

(b) Senegal

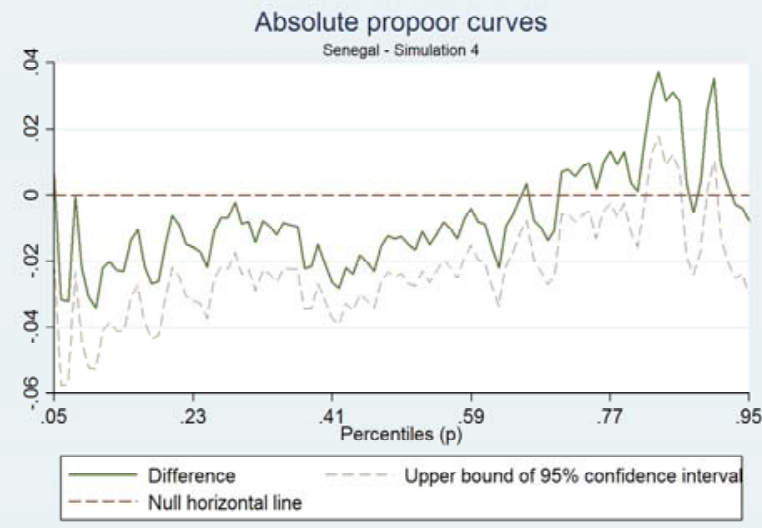

Source: Computed by authors from ESAM I and EMEP with the DASP package.

The situation for Senegal is different, since lower percentiles (below 50\%) have smaller income growth compared to higher percentiles (above 50\%). The pro-poor indices do not allow us to draw clear conclusions for the pro-poverty of this policy since we obtain contradictory effects with different indices ${ }^{21}$. The results are quite similar at the rural level (see Table 11 in appendix). Hence, the pro-poor analysis performed on the two policies applied to respond to the food crisis reveals that the increase in agricultural land use is more efficient in helping the most deprived in the two countries.

\section{Conclusion and recommendations}

In this paper we used two macro-micro CGE models to analyse the impact of the Food Crisis on two neighbouring West African countries, and to examine two policy responses. At first glance, these countries seem very similar. They share a similar Sahelian climate, a large portion of their populations rely on agriculture for their income, the size of agriculture in their economies (around 23\% of GDP for both countries) relies on a strong industrial agriculture product (groundnut for Senegal and cotton for Mali), and both countries have high poverty rates (between 60 and 70\%). Both countries have a relatively similar food consumption basket.

\footnotetext{
${ }^{21}$ The gaps between the poverty equivalent growth rate (PEGR), the absolute rate of pro-poor growth, and the growth rates have been tested not significant at $5 \%$.
} 
A priori one would have expected similar distribution impact of this crisis, namely for poverty and inequality. Table 8 in the appendix illustrates that most structural elements of the agricultural sector in the two countries are quite similar, with the exception of export and import structure.

The comparative analysis was performed using the same models with identical macro closure rules and similar trade elasticities and household behaviour. Our results reveal major differences in the poverty, inequality, and pro-poor indices. These differences were observed at the national level for all indices for at least one simulation, and for at least one group in each simulation. For poverty comparisons, in Senegal, the rural households seem to bear the brunt of the external shocks when they are the ones least affected in Mali. For urban households, we have the opposite result, with positive effects in Senegal and negative effects in Mali. The increase in land use has slighter impact in urban centers in Senegal compared to Mali.

As for inequality, the reversal of effects is even clearer between the two countries at the national level and for group decomposition. We only observe a few significant exceptions for the second simulation at the national level, with the same qualitative effect in the two countries. Simulation 3 also exhibits the same qualitative impact in the two countries for residents of capital regions. All other effects are either opposite or insignificant.

Finally, our four pro-poor indicators also reveal important differences between the impacts in the two countries. In fact, the origins of the differences lie in structural differences between the two countries in many areas. Among these are the structure of trade for agricultural goods, with a high proportion of cereal imports for Senegal compared to Mali, the large portion of exported agricultural goods produced in Mali, the important role of the structure of the rest of the economy, and the income and expenditure structure of poor households in the two countries. Therefore, two countries which seem similar at first glance have sufficient structural differences to produce qualitative and quantitative differences in terms of the distributional impact of the food crisis and compensatory measures. This is an important finding insofar as strong caveats should be associated with the extrapolation of conclusions from one developing country to another. One cannot conclude on the distributional impact of the food crisis in a given country without performing a rigorous analysis of the country in question. 


\section{Bibliography}

Adelman, I. and S. Robinson (1978), Income Distribution Policy: A Computable General Equilibrium Model of South Korea, Stanford: Stanford University Press.

ANSD, (2008), "Évolution annuelle de l'indice harmonisé des prix à la consommation en 2007", Ministère de l'économie et des finances, Direction des Statistiques Économiques et de la Comptabilité Nationale, http://www.ansd.sn/publications/annuelles/EvolAnnuel_IHPC_2007.pdf.

Araar Abdelkrim and Jean-Yves Duclos (2007), "DASP: Distributive Analysis Stata Package", PEP, CIRPÉE and World Bank, Université Laval.

Armington P. S. (1969) "A Theory of Demand for Products Distinguished by Place of Production », IMF staff paper, $\mathrm{n}^{\circ}$ 16, p. 159-176.

Boccanfuso, D. and L. Savard, (2007) Une analyse d'impact économique et social de la cohérence des politiques économiques et aide publique au développement au Sénégal : Un cadre macro-micro, GREDI, Working Paper 07-21, Université de Sherbrooke, Québec, Canada.

Boccanfuso, D., M. Coulibaly and L. Savard, (2008) Une analyse d'impact économique et social des réformes économiques et de l'aide publique au développement au Mali - Un cadre macro-micro, , European Journal of Development Research, Volume 20, no 3 p. 518-544

Boccanfuso, D. and C. Ménard, (2008), "La croissance pro-pauvre : un aperçu exhaustif de la «boite à outils »", Cahier de recherche du GRÉDI \#09-06, Université de Sherbrooke, Québec, Canada.

Boccanfuso, D., Estache, A. and L. Savard, (2009), Impact Analysis of Electricity reforms in Senegal: A Macro-micro analysis, Journal of Development Studies. Volume 45, no 3 p. p. 351-375.

Bourguignon, F., and L. Savard, (2008) "Distributional Effects of Trade Reform: An Integrated MacroMicro Model Applied to the Philippines" dans Bourguignon, F. L.A. Pereira da Silva, et M. Bussolo, eds. "The Impact of Macroeconomic Policies on Poverty and Income Distribution Macro-Micro Evaluation Techniques and Tools" Palgrave-Macmillan Publishers Limited, Houndmills.

Cabral F. J., (2005), “Accord agricole et redistribution des revenus en milieu rural au Sénégal : essai de simulation à l'aide d'un modèle d'équilibre général calculable", Thèse de Doctorat d'État, FASEG/UCAD, Dakar.

Cabral, F. J., (2008), "Insécurité alimentaire en milieu urbain et rural au Sénégal : les mêmes causes créent-elles les mêmes effets ? ", Cahier du GRÉDI \#08-12, Université de Sherbrooke.

Chen S. and M. Ravallion (2004) Welfare Impacts of China's Accession to the World Trade Organization, The World Bank Economic Review, vol 18, n 1, p. 29-57.

Chia, N. -C., S. Wahba and J. Whalley (1994), « Poverty-Reduction Targeting Programs: a General Equilibrium Approach», Journal of African Economies, Vol. 3 no. 2, pp. 309-338.

Cockburn, J. (2001), "Trade liberalization and Poverty in Nepal: A Computable General Equilibrium Microsimulation Analysis », Cahier de recherche 01-18. CREFA, Université Laval.

Cogneau D. and A.-S Robillard (2000), "Income Distribution, Poverty and Growth in Madagascar: Micro simulations in a General Equilibrium Framework », IFPRI TMD Discussion Paper No.61.

Decaluwé, B., A. Patry, L. Savard and E. Thorbecke (1998), « Poverty Analysis Witbin a General Equilibrium Framework» Collaborative Research project CR-2-4, African Economic Research Consortium.

Decaluwé, B., J.C. Dumont and L. Savard (1999), "How to Measure Poverty and Inequality in General Equilibrium Framework», Laval University, CREFA Cahier de recherche \#9920.

Decaluwé B., L. Savard and E. Thorbecke, (2005), General Equilibrium Approach for Poverty Analysis: With an Application to Cameroon, African Development Review, vol 17, n² 2, p. 213-243. 
de Janvry, A., E. Sadoulet and A. Fargeix (1991), "Adjustment and Equity in Ecuador » OECD Development Center, Paris.

Dervis, K, J. de Melo and S. Robinson, (1982), "General Equilibrium Models for Development Policy», Cambridge University Press, London, pp. 1-526.

FAO, (1974), "Council of FAO - Report of the 64th Session", 110 pages; http://www.fao.org/docrep/meeting/007/F5340F/F5340F00.HTM.

FAO, (2002a), "Report of the World Food Summit: five years later. Part One", 236 pages; ftp://ftp.fao.org/docrep/fao/meeting/005/y7106e.pdf.

FAO, (2002b), "FAO/WFP crop and food supply assessment mission to Senegal", Special Reports and Alerts (GIEWS), http://www.fao.org/docrep/005/Y8165E/Y8165E00.htm\#19.

FAO, (2004), "FAO/WFP crop and food supply assessment mission to Mali, with special focus on losses due to the desert locust", Special Reports and Alerts (GIEWS), ftp://ftp.fao.org/docrep/fao/007/j3971e/j3971e00.pdf.

FAO, (2008a), "Assessment of the world food security and nutrition situation", Committee on World Food Security, 34th session, ftp://ftp.fao.org/docrep/fao/meeting/014/k3175e.pdf.

FAO, (2008b), "The State of Food and Agriculture 2008. Biofuels: prospects, risks and opportunities, FAO Agriculture Series (SOFA), 240 pages, ftp://ftp.fao.org/docrep/fao/011/i0100e.

FAO, (2008c), "Crop Prospects and Food Situation", Giews publication \#4, ftp://ftp.fao.org/docrep/fao/011/ai473e/ai473e00.pdf.

Foster, J.E., J. Greer and E. Thorbecke (1984), "A Class of Decomposable Poverty Indices", Econometrica, 52, pp.761-766.

Glauber, J., USDA Chief Economist, in testimony before the Joint Economic committee of Congress on May 1, 2008.

Hertel T. and J. Reimer (2004) «Predicting the Poverty Impacts of Trade Reform», World Bank Policy Research Working Paper $n^{\circ}$ 3444, World Bank, Washington.

Kakwani, N. and E. Pernia, (2001), "What is Pro-Poor Growth?", Asian Development Review Vol 18, 1.

Kakwani, N. and H. Son (2002), "Pro-Poor Growth: Concept, Measurement, and Application", unpublished mimeo, University of New South Wales, Sydney: Australia.

Mitchell, D., (2008), “A note on rising food prices”, Policy Research working paper; no. WPS 4682.

Ravallion, M., (1994), « Poverty Comparisons », Harwood academic publishers, 143 pages.

Ravallion, M. and S. Chen (2003). "Measuring Pro-Poor Growth", World Bank, Policy Research Working Paper 2666.

Rutherford T., D. Tarr and O. Shepotylo, (2005) «Poverty effects of Russia's WTO accession: modeling "real" household and endogenous productivity effects ", World bank policy research working paper $n^{\circ} 3473$, Banque mondiale, Washington.

Savard, L. (2005) "Poverty and Inequality Analysis within a CGE Framework: A Comparative Analysis of the Representative Agent and Micro-Simulation Approaches." Development Policy Review, vol. 23, n 3, p 313332.

Savard, L. (2006) Analyse de pauvreté et distribution des revenus dans la cadre de la modélisation en équilibre général calculable.? Phd thesis, PSE-École des Hautes Études en Sciences Sociales, Paris. 
Taylor, L. and F. Lysy (1979) Vanishing Income Redistributions: Keynesian Clues about Model Surprises in the Short-Run, Journal of Development Economics, vol 6, n 1, p. 11-29.

USAID, 2008, "Mali Food Security Outlook 2008”, http://www.usaid.gov/ml/documents/food $\% 20$ security $\% 20$ updates $/$ mali_fsu_2008 07 en.pdf.

\section{Annexes}

Table 7 : Cereal balance assessment (in thousand tons)

\begin{tabular}{|c|c|c|c|c|}
\hline \multicolumn{5}{|c|}{ Senegal (2002-03) } \\
\hline & Rice & Wheat & Coarse grains & Total \\
\hline Availability & 402,31 & 20,94 & 703,25 & 1126,50 \\
\hline Stocks & 182,95 & 20,94 & 21,1 & 224,99 \\
\hline National production & 219,36 & 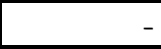 & 682,15 & 901,51 \\
\hline Total needs & 990,83 & 277,74 & 914,37 & 2182,93 \\
\hline Imports and food aid & 588,52 & 256,8 & 211,12 & 1056,44 \\
\hline \multicolumn{5}{|c|}{ Mali (2004-05) } \\
\hline & Rice & Wheat & Coarse grains & Total \\
\hline Availability & 877 & 7 & 2050 & 2934,00 \\
\hline Stocks & & - & - & \\
\hline National production & 877 & 7 & 2050 & 2934 \\
\hline Total needs & 854,8 & 68,5 & 2028,4 & 2951,70 \\
\hline Imports and food aid & $-22,2$ & 61,5 & $-21,6$ & 17,70 \\
\hline
\end{tabular}

Sources: FAO (2002b); FAO (2004)

Table 8 : Structural characteristics of agriculture

\begin{tabular}{|l|c|c|c|c|}
\hline & $\begin{array}{c}\text { Total output } \\
(\mathrm{XS}) / \text { GDP }\end{array}$ & $\begin{array}{c}\text { Exports } \\
(\mathrm{EX}) / \mathrm{XS}\end{array}$ & $\begin{array}{c}\text { Imports (Im) } \\
\text { / domestic } \\
\text { demand (Q) }\end{array}$ & $\begin{array}{c}\text { Value Added } \\
\text { (VA) /XS }\end{array}$ \\
\hline \hline \multicolumn{5}{|c|}{ Mali } \\
\hline \multicolumn{5}{|c|}{ Semegal } \\
\hline \hline Total Agriculture & 0,24 & 0,19 & 0,08 & 0,85 \\
\hline \hline Total Agriculture & 0,23 & 0,01 & 0,23 & 0,51 \\
\hline
\end{tabular}

Table 9 : Simulations

\begin{tabular}{|c|c|c|}
\hline Code & Scenario & Simulations in model \\
\hline Sim 1 & $\begin{array}{l}\text { Agricultural price } \\
\text { increase }\end{array}$ & $\begin{array}{l}\text { World price of imports and exports for agricultural sector } \\
\text { increased by } 70 \%\end{array}$ \\
\hline $\operatorname{Sim} 2$ & $\begin{array}{l}\text { Agricultural import } \\
\text { price increase }\end{array}$ & World price of agriculture sector imports increased by $70 \%$ \\
\hline $\operatorname{Sim} 3$ & $\begin{array}{c}\text { Sim } 1+\text { expension of } \\
\text { land use }\end{array}$ & $\begin{array}{l}\text { Sim } 1 \text { and an increase in } 30 \% \text { of agricultural capital resulting } \\
\text { from land reform use policy }\end{array}$ \\
\hline $\operatorname{Sim} 4$ & $\begin{array}{c}\text { Sim } 2+\text { elimination of } \\
\text { import duties }\end{array}$ & $\begin{array}{l}\text { Sim } 2 \text { and the elimination of import duties for agricultural } \\
\text { imports }\end{array}$ \\
\hline
\end{tabular}


Table 10 : Variation of poverty indexes (\%)

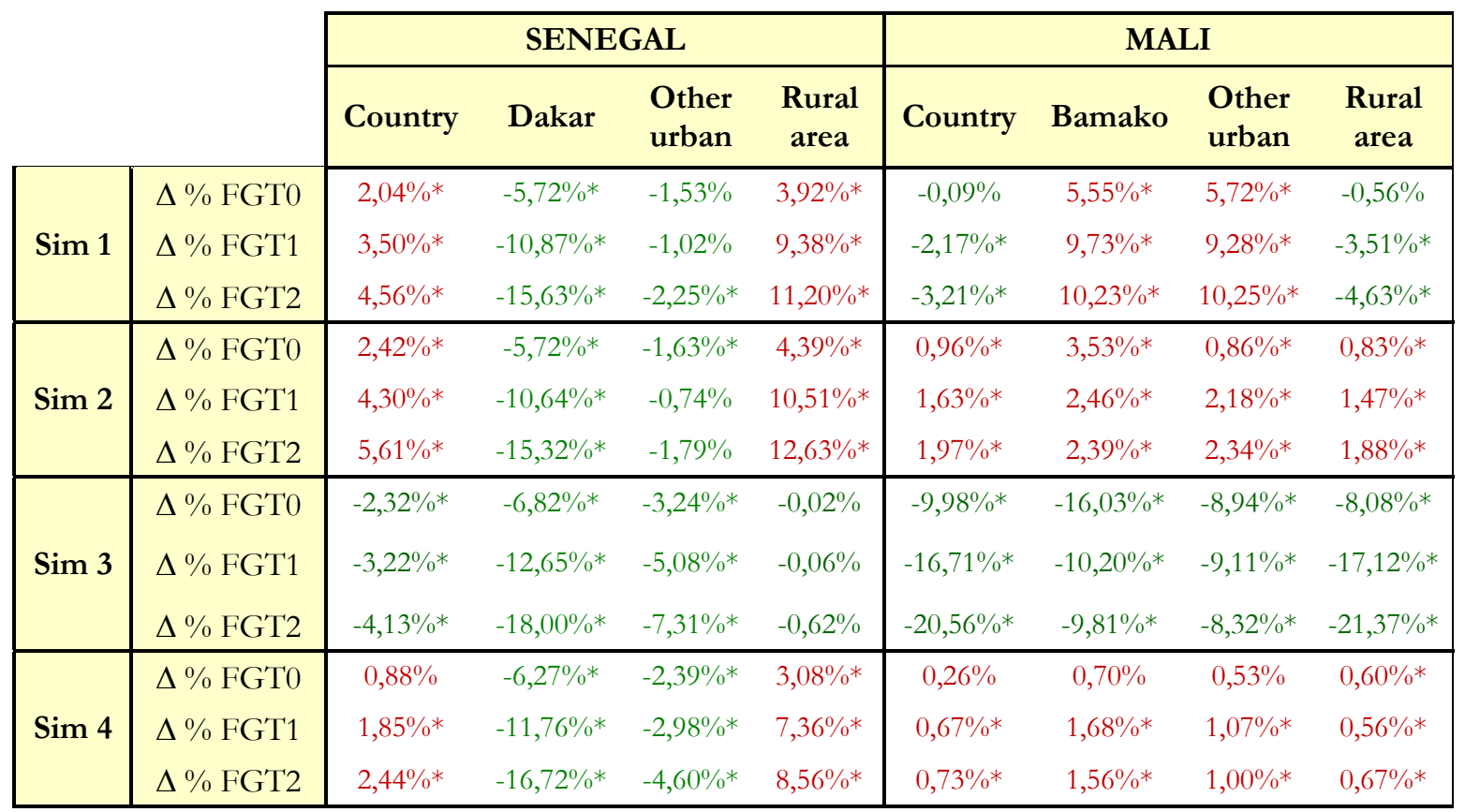

Source: Computed by authors from ESAM I and EMEP with DASP package. * Significant at $5 \%$.

Table 11: Pro-poor growth analysis

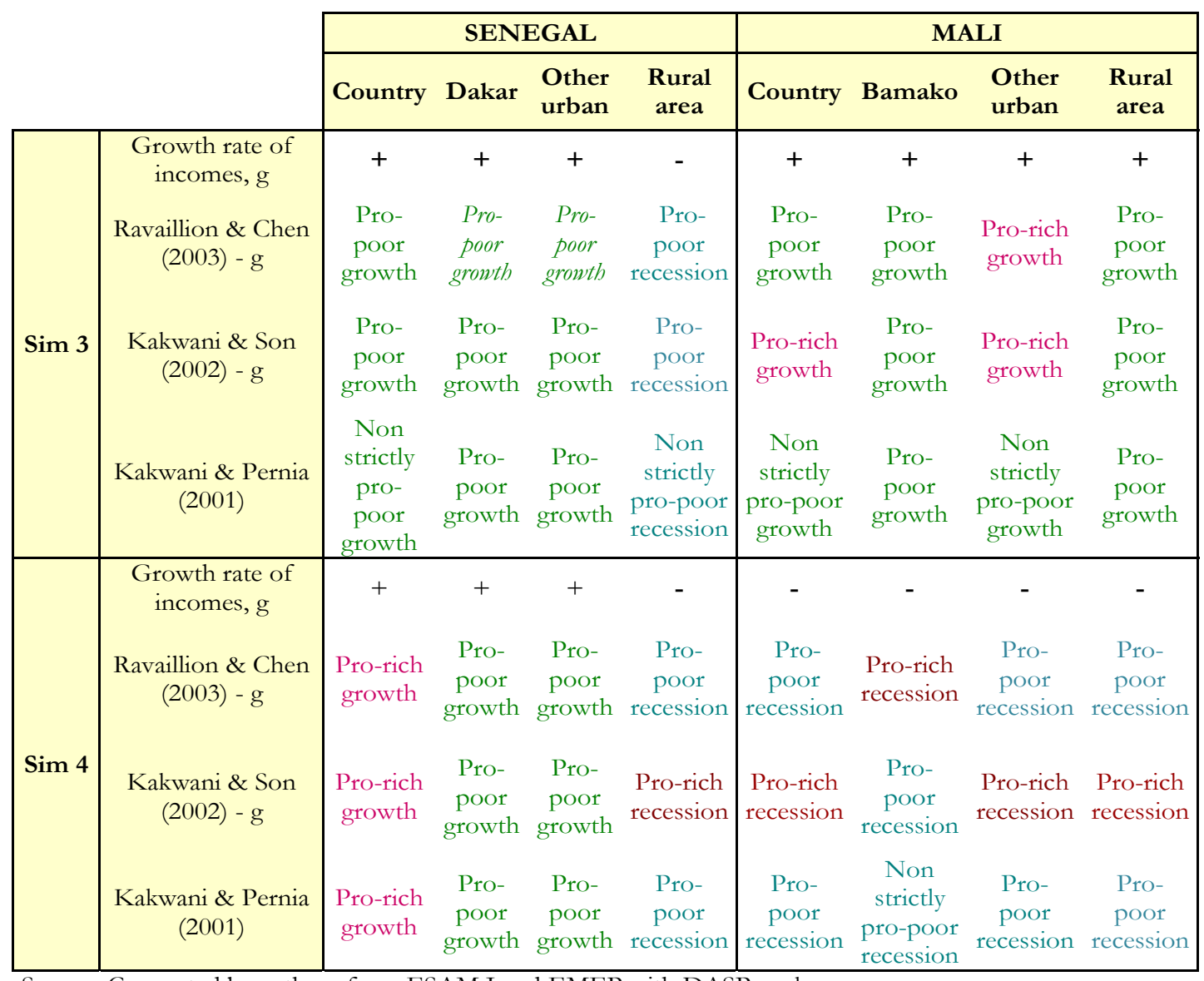

Source: Computed by authors from ESAM I and EMEP with DASP package. 
Figure 9: Growth incidence curve for rural areas in (a) Mali (b) Senegal (Simulation 4)

(a) Mali

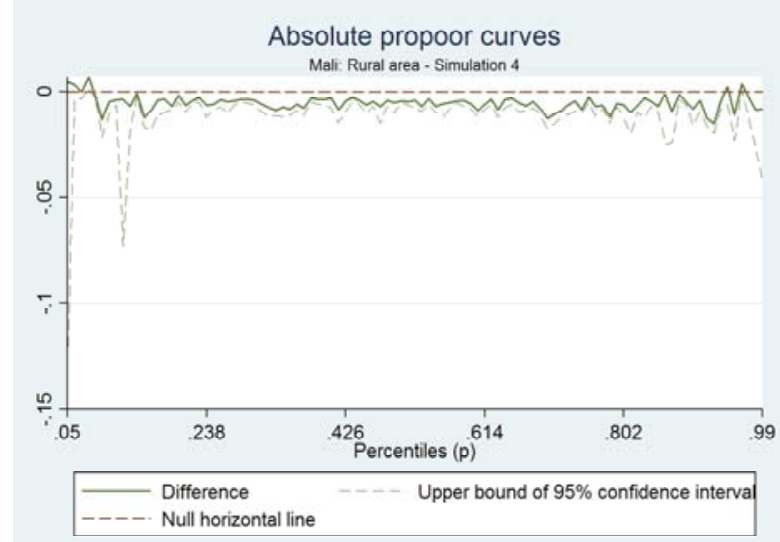

(b) Senegal

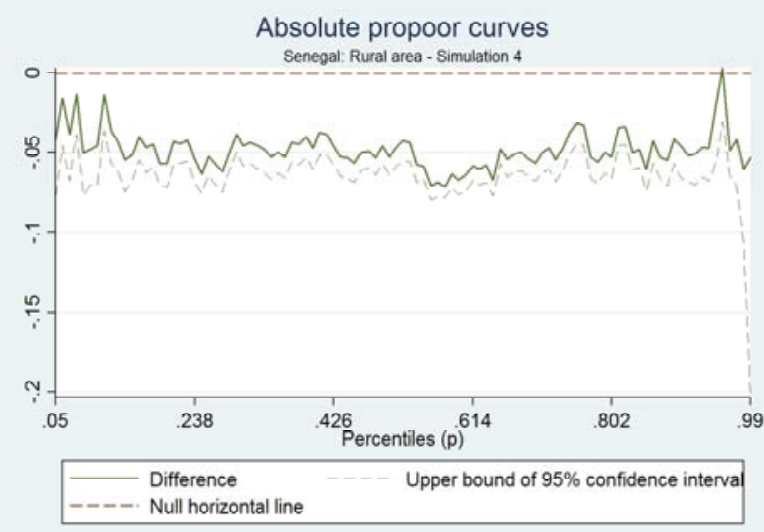

Source: Computed by authors from ESAM I and EMEP with DASP package. 